http://jurnalsttn.ac.id/index.php/SJT

p-ISSN 2772-3078, e-ISSN 2772-306X
Sekolah Tinggi Teologi Nusantara, Salatiga

Edisi: Volume 2, Nomor 2, November 2021

\title{
Efektifitas Model Pembelajaran Jarak Jauh Di Sekolah Tinggi Teologi Kristus Alfa Omega Semarang
}

\author{
Eni Rombe
}

Sekolah Tinggi Teologi Kristus Alfa Omega, Semarang enirombe41@gmail.com

Yusuf Bumbungan

Sekolah Tinggi Teologi Kristus Alfa Omega, Semarang

Justo.bumbungan@gmail.com

Temazatolu Lase

Sekolah Tinggi Teologi Kristus Alfa Omega, Semarang

themalace@gmail.com

\section{Article History \\ Submit: \\ October $14^{\text {th }}, 2021$}

Revised:

November 1st, 2019

Published:

December13'rd, 2021

\section{Abstrak:}

Pendidikan merupakan salah satu hak asasi bagi setiap manusia. Setiap warga negara Indonesia berhak mendapatkan layanan Pendidikan. Selain menjadi hak asasi pendidikan juga merupakan sutau hal yang sangat penting dan berpengaruh dalam kehidupan manusia. Bahkan bisa dikatakan bahwa pendidikan merupakan sektor yang sangat strategis dalam meningkatkan kualitas sumber daya menusia dan mencerdaskan kehidupan bangsa. pembelajaran yang diterapkan saat ini adalah model pembelajaran jarak jauh. Pembelajaran jarak jauh dilaksanakan secara online pada masa pendemi sejak tahun 2020. Pelaksanaan proses pembelajaran jarak jauh ini memberi peluang bagi peserta didik yang berada diberbagai daerah untuk mendapatkan layanan pendidikan. Penelitian ini bertujuan untuk mengukur efektivitas model pembelajaran jarak jauh yang telah diterapkan di Sekolah Tinggi Teologi Kristus Alfa Omega, Semarang.

Kata kunci: Efektivitas, Model Pembelajaran Jarak Jauh

Abstract: Education is a human right for every human being. Every Indonesian citizen is entitled to education services. In addition to being a human right of education is also a very important and influential thing in human life. One of the learning models applied today is the distance learning model. Distance learning is carried out online at the time of emigrants since 2020. The implementation of this distance learning process provides opportunities for learners who are in various regions to get educational services. This research aims to measure the effectiveness of distance learning models that have been applied at Sekolah Tinggi Teologi Kristus Alfa Omega, Semarang. 
http://jurnalsttn.ac.id/index.php/SJT

p-ISSN 2772-3078, e-ISSN 2772-306X
Sekolah Tinggi Teologi Nusantara, Salatiga

Edisi: Volume 2, Nomor 2, November 2021

\section{Pendahuluan}

Pendidikan merupakan salah satu hak asasi bagi setiap manusia. Setiap warga negara Indonesia berhak mendapatkan layanan Pendidikan. Bahkan dijelaskan bahwa negara wajib membiayai Pendidikan bagi warganya. Hal ini dijelaskan dalam UU Nomor 20 Tahun 2003 Pasal 31 Ayat 1 dan 2, yaitu: 1) Setiap warga negara berhak mendapat pendidikan. 2) Setiap warga negara wajib mengikuti pendidikan dasar dan pemerintah wajib membiayainya. ${ }^{1}$ Pemerintah memiliki tugas dan tanggung jawab untuk mengusahakan dan menyelenggarakan Sistem Pendidikan Nasional. Hal ini juga dijelaskan dalam UU Nomor 20 Tahun 2003 Pasal 31 khusunya di Ayat 3, yaitu:

(3) Pemerintah mengusahakan dan menyelenggarakan satu sistem pendidikan nasional, yang meningkatkan keimanan dan ketakwaan serta akhlak mulia dalam rangka mencerdaskan kehidupan bangsa, yang diatur dengan undang-undang. ${ }^{2}$

Menyelenggarakan Pendidikan berarti negara harus menyediakan tempat/sekolah, pendidik, sarana dan prasarana sehingga kegiatan belajar belajar mengajar tersebut dapat terlaksana dengan baik. Pendidikan yang diselenggarakan oleh pemerintah adalah pendidikan nasional, yang juga diatur dalam UU No. 20 Tahun 2003 Pasal 1 Ayat 2 yaitu:

"Pendidikan nasional adalah pendidikan yang berlandaskan Pancasila dan Undang-Undang Dasar Negara Republik Indonesia Tahun 1945 yang berakar pada nilai-nilai agama, kebudayaan nasional Indonesia dan tanggap terhadap tuntutan perubahan zaman." 3

Pendidikan nasional yang diselenggarakan oleh pemerintah adalah dengan cara menyediakan tempat/sekolah, pendidik, sarana dan prasana maka semua anak warga

1Undang-Undang Dasar Tahun 1945 tetang Pendidikan, Pasal 31 Ayat (1) Dan (2), n.d. 2Peraturan Pemerintah RI, UU No. 20 Tahun 2003 Pasal 1, UU Pendidikan Nasional, 2003. 3Peraturan Pemerintah RI, Pasal 1 Ayat 2 \& 3 Undang-Undang Nomor 20 Tahun 2003, 2003. 
http://jurnalsttn.ac.id/index.php/SJT

p-ISSN 2772-3078, e-ISSN 2772-306X
Sekolah Tinggi Teologi Nusantara, Salatiga

Edisi: Volume 2, Nomor 2, November 2021

negara Indonesia dapat menikmati pendidikan. Dimana pendidikan tersebut bertujuan untuk mencerdaskan warga negaranya, sehingga mampu menguasai ilmu pengetahuan dan teknologi. Seperti yang juga tertuang dalam UU No. 20 Tahun 2003 pasal 3 yang berbunyi:

"Pendidikan nasional berfungsi mengembangkan kemampuan dan membentuk watak serta peradaban bangsa yang bermartabat dalam rangka mencerdaskan kehidupan bangsa, bertujuan untuk berkembangnya potensi peserta didik agar menjadi manusia yang beriman dan bertakwa kepada Tuhan Yang Maha Esa, berakhlak mulia, sehat, berilmu, cakap, kreatif, mandiri, dan menjadi warga negara yang demokratis serta bertanggung jawab." 4

Berdasarkan pemaparan di atas dapat dipahami bahwa pendidikan merupakan sutau hal yang sangat penting dan berpengaruh dalam kehidupan manusia. Bahkan bisa dikatakan bahwa pendidikan merupakan sektor yang sangat strategis dalam meningkatkan kualitas sumber daya menusia dan mencerdaskan kehidupan bangsa.

Proses pembelajaran merupakan sistem yang digunakan untuk meningkatkan kualitas pendidikan. Pembelajaran merupakan suatu sistem yang terdiri dari berbagai komponen yang saling berhubungan satu dengan yang lain. ${ }^{5}$ Komponen-komponen yang terdapat dalam sistem pembelajaran yaitu; tujuan, materi, metode, dan evaluasi. Pembelajaran merupakan interaksi antara pendidik dengan peserta didik dengan menggunakan berbagai media dan pola pembelajaran. Sejalan dengan pendapat di atas menurut warsita "Pembelajaran adalah suatu usaha untuk membuat peserta didik belajar atau suatu kegiatan untuk membelajarkan peserta didik." ${ }^{6}$ Dengan kata lain, pembelajaran merupakan upaya menciptakan kondisi agar terjadi kegiatan belajar.

\footnotetext{
4Peraturan Pemerintah RI, UU No 20 Tahun 2003 Pasal 3 Fungsi Pendidikan, 2003.

${ }^{5}$ Rusman, Belajar \& Pembelajaran: Orientasi Standar Proses Pendidikan (Jakarta: Prenadamedia Group, 2018), 84.

${ }^{6}$ Bambang Warsita and Teknologi Pembelajaran, Landasan Dan Aplikasinya, Jakarta: Rineka Cipta, vol. 135 (Jakarta: Rineka Cipta, 2008).
} 
http://jurnalsttn.ac.id/index.php/SJT

p-ISSN 2772-3078, e-ISSN 2772-306X
Sekolah Tinggi Teologi Nusantara, Salatiga

Edisi: Volume 2, Nomor 2, November 2021

Bahkan lebih lanjut Sudjana memberikan pengertian tentang pembelajaran sebagai berikut; pembelajaran adalah upaya yang sistematik dan sengaja untuk menciptkan agar terjadi kegiatan interaksi edukatif antara dua pihak, yaitu antara peserta didik dengan pendidik yang melakukan kegiatan membelajarkan. ${ }^{7}$

Berdasarkan pernyataan di atas pembelajaran dapat dikatakan sebagai suatu proses interaksi komunikasi antara sumber belajar, pendidik dan peserta didik. Interaksi komunikasi tersebut dilakukan secara langsung dalam kegiatan tatap muka maupun secara tidak langsung dengan menggunakan media, di mana sebelumnya telah menentukan model pembelajaran yang akan diterapkan. Salah satu model pembelajaran yang ada dalam dunia pendidikan adalah model pembelajaran jarak jauh. Model pembelajaran jarak jauh dikenal juga dengan istilah "distance learning" merupakan proses pembelajaran yang dilaksanakan dimana terdapat pemisahan antara pengajar dan peserta didik secara ruang dan waktu. ${ }^{8}$

Model pembelajaran jarak jauh sudah diterapkan di Indonesia, seperti Universitas Terbuka. Proses pembelajaran biasanya dilakukan dengan mengirimkan berbagai materi pelajaran dan informasi dalam bentuk cetakan, buku, CD-ROM, atau video langsung ke alamat pembelajaran. Dalam pembelajaran jarak jauh materi pelajaran juga dapat dismpaikan secara langsung tanpa kehadiran peserta didik dan pendidik di tempat yang sama. Dengan perkembangan teknologi informasi dan komunikasi, khususnya perkembangan teknologi komputer dengan internetnya juga berdampak kepada berkembangnya penerapan model pembelajaran jarak jauh.

Sejak diterbitkan Surat Edaran Kemdikbud Nomor 15 Tahun 2020 tentang Pedoman Penyelenggaraan Belajar dari Rumah dalam masa darurat penyebaran Covid19, pembelajaran lakukan secara jarak jauh, baik dari (dalam jaringan) maupun luring

7Sudjana, Dasar-Dasar Proses Belajar Mengajar (Bandung: Sinar Baru Algensindo Offset, 2004), 28.

${ }^{8}$ Ahmad Johari Sihes, Konsep Pembelajaran, E-Prints UTM (Yogyakarta: Gava Media, 2015), http:/ / repository.usu.ac.id/bitstream/123456789/23790/4/Chapter I.pdf, 61. 
http://jurnalsttn.ac.id/index.php/SJT

p-ISSN 2772-3078, e-ISSN 2772-306X
Sekolah Tinggi Teologi Nusantara, Salatiga

Edisi: Volume 2, Nomor 2, November 2021

(luar jaringan). Kondisi darurat Covid-19 berdampak pada proses pembalajaran. ${ }^{9}$ Proses pembejaran di Indonesia yang secara umum dilakukan dengan carat atap muka secara langsung antara pendidik dengan peserta didik dalam satu tempat dan waktu yang sama menjadi pembelajaran jarak jauh dimana pendidik dan peserta didik berada di tempat yang berbeda namun pada waktu yang bersamaan. ${ }^{10}$ Sejak itulah maka di Indonesia secara serentak menerapkan model pembelajaran jarak jauh.

Hal inilah yang juga dilakukan di Sekolah Tinggi Teologi Kristus Alfa Omega Semarang. Sejak tahun 2020 Sekolah Tinggi Teologi Kristus Alfa Omega semarang juga mengikuti Surat Edaran Kemdikbud Nomor 15 Tahun 2020 tentang Pedoman Penyelenggaraan Belajar dari Rumah. Sehingga proses pembelajaran tidak lagi dilakukan secara tatap muka secara langsung, tetapi menjadi proses perkuliahan online. Sehingga model pembelajaran yang diterapkan adalah model pembelajaran jarak jauh.

\section{Metodologi Penelitian}

Adapun metode penelitian yang digunakan dalam penelitian ini adalah jenis penelitian deskriptif. Penelitian deskripstif adalah penelitian yang mengumpulkan data yang ditujukan untuk menggambarkan fenomena yang ada yang berlangsung pada saat itu dan saat yang telah lalu baik itu keadaan, objek orang atau peristiwa. ${ }^{11}$ Sudarwan Danim mengatakan bahwa tujuan penggunaan jenis penelitian deskriptif adalah untuk mendeskripsikan suatu situasi atau area populasi tertentu yang bersifat faktual, secara sistematis, dan akurat. Lebih sederhananya adalah untuk mendeskripsikan seperangkat peristiwa atau kondisi populasi saat ini. ${ }^{12}$ Berdasarkan pandangan ini maka, peneliti

\footnotetext{
9Sarwa, Pembelajaran Jarak Jauh: Konsep, Masalah Dan Solusi (Indramayu: Adab, 2021), 1. https://books.google.co.id/books?id=OdQeEAAAQBAJ\&dq=Kurikulum+pembelajaran+jarak+jauh\&lr= \&hl=id\&source=gbs_navlinks_s.

${ }^{10} \mathrm{Ibid}, 2$.

${ }^{11}$ Giedre Valunaite Oleskeviciene and Jolita Sliogeriene, Research Methodology, Numanities - Arts and Humanities in Progress, vol. 13 (Semarang: KAO Press, 2020), 16.

${ }^{12}$ Danim Sudarwan, Menjadi Peneliti Kualitatif, 1 (Bandung: CV. Pustaka Setia, 2002), 41.
} 
http://jurnalsttn.ac.id/index.php/SJT

p-ISSN 2772-3078, e-ISSN 2772-306X
Sekolah Tinggi Teologi Nusantara, Salatiga

Edisi: Volume 2, Nomor 2, November 2021

menyimpulkan bahwa metode penelitian kuantitatif deskriptif cocok digunakan dalam penelitian ini karena sesuai dengan tujuan penelitiannya, yaitu memperoleh gambaran tentang “Efektivitas Model Pembelajaran Jarak Jauh di Sekolah Tinggi Teologi Kristus Alfa Omega, Semarang Tahun 2021."

\section{Pembahasan}

\section{a. Pengertian Pembelajaran Jarak Jauh}

Pembelajaran jarak jauh adalah sekumpulan metode pengajaran di mana aktivitas pengajaran dilaksanakan secara terpisah dari aktivitas belajar. Pemisahan kedua kegiatan tersebut dapat berupa jarak fisik, misalnya karena peserta didik bertempat tinggal jauh dari lokasi institusi pendidikan. Pemisahan dapat pula berjarak nonfisik yaitu berupa keadaan yang memaksa seseorang yang tempat tinggal dekat dari lokasi institusi pendidikan, namun tidak dapat mengikuti kegiatan pembelajaran di institusi tersebut. Keterpisahan kegiatan pengajaran dari kegiatan belajar adalah ciri khas dari pendidikan jarak jauh.

Sistem pendidikan jarak jauh merupakan suatu alternatif pemerataan kesempatan dalam bidang pendidikan. Sistem ini dapat mengatasi beberapa masalah yang ditimbulkan akibat keterbatasan tenaga pengajar yang berkualitas. Pada sistem pendidikan pelatihan ini tenaga pendidik dan peserta didik tidak harus berada dalam lingkungan geografis yang sama. ${ }^{13}$ Sejalan dengan pandangan Daryanto dan Tasrial bahwa konsep pembelajaran jarak jauh dikenal juga dengan istilah 'distance learning' atau 'distance education' yaitu suatu sistem pendidikan dimana terdapat pemisahan antara pendidik dengan peserta didik baik secara ruang dan atau waktu. ${ }^{14}$

13H. Hamzah B Uno, Model Pembelajaran: Menciptakan Proses Belajar Mengajar Yang Kreatif Dan Efektif, Jakarta: Bumi Aksara (Jakarta: Bumi Aksara, 2010), 34.

${ }^{14}$ Ahmad Johari Sihes, Konsep Pembelajaran, 61. 
http://jurnalsttn.ac.id/index.php/SJT

p-ISSN 2772-3078, e-ISSN 2772-306X
Sekolah Tinggi Teologi Nusantara, Salatiga

Edisi: Volume 2, Nomor 2, November 2021

Pendidikan jarak jauh adalah pendidkan yang peserta didiknya terpisah dari pendidik dan pemebalajarannya menggunakan berbagai sumber belajar melalui tenologi informasi dan komunikasi dan media lain. 15 Sedangkan pengertian pembelajaran jarak jauh dari berbagai macam sudut pandang para ahli yang telah dirangkum oleh Paulina Pannnen dalam buku Tian Belawati, yaitu sebagai berikut: ${ }^{16}$

- Suatu bentuk pembelajaran mandiri yang terorganisasi secara sistematis, dimana konseling, penyaji materi pembelajaran, dan penyedia serta pemantauan keberhasilan peserta didik dilakukan oleh sekelompok tenaga pengajar yang memiliki tanggung jawab yang saling berbeda. Pembelajaran dilaksanakan secara jarak jauh dengan menggunakan bantuan media. Sebaliknya Pendidikan jarak jauh adalah sistem Pembelajaran yang terjadi karena adanya kontak langsung antar tenaga pengajar dengan peserta didik (Dhmen, 1967).

- Suatu metode pembelajaran yang menggunakan korespondensi sebagai alat komunikasi antar pengajar dengan peserta didik ditambah dengan adanya interaksi (MacKenzie, Christensen \& Rigby, 1968).

- Sistem Pendidikan yang tidak mempersyaratkan adanya tenaga pendidik di tempat seorang peserta didik, namun dimungkinkan adanya pertemuanpertemuan antara tenaga pendidik dan peserta didik pada waktu-waktu tertentu (Frech Law, 1971).

- Suatu metode untuk menyampaikan ilmu pengetahuan, keterampilan dan sikap yang dikola berdasarkan pada penerapan konsep dan berjalan, prinsip-prinsip organisasi, dan pemanfaatan media secara ekstensif terutama dalam reproduksi bahan ajar (Paters, 1973).

- Suatu metode pembelajaran dimana proses pengajaran terjadi secara terpisah dari proses belajar sehingga komunikasi antara tenaga pendidik dan peserta didik

\footnotetext{
15Peraturan Pemerintah RI, Undang Undang Republik Indonesia Tahun2003 Nomor 2003 Pasal 1 Ayat 15., n.d.

${ }^{16}$ Setijadi, Pendidikan Terbuka Dan Jarak Jauh, Universitas Terbuka (Jakarta: Pusat Penerbitan Universitas tebuka, 2009), http://repository.ut.ac.id/5653/1/UTPTJJE2-ALL.pdf.
} 


\section{Sabda: Jurnal Teologi Kristen}

http://jurnalsttn.ac.id/index.php/SJT

p-ISSN 2772-3078, e-ISSN 2772-306X
Sekolah Tinggi Teologi Nusantara, Salatiga

Edisi: Volume 2, Nomor 2, November 2021

harus difasilitasi melalui bahan cetak, media elektronik dan media-media lain (Moore, 1973).

- Suatu bentuk Pendidikan yang meliputi beragam bentuk pembelajaran pada berbagai tingkat pendidkan yang terjadi tanpa adanya penyediaan tutor secara langsung dan atau secara terus menerus terhadap peserta didik dalam suatu lokasi yang sama namun memerlukan proses perencanaa, pengorganisasian Pendidikan serta penyediaan proses.

b. Tujuan Pembelajaran Jarak Jauh

Tujuan dari pembangunan sistem ini antara lain menerapkan aplikasi pendidikan jarak jauh yang berbasis web pada situs-situs pendidikan jarak jauh yang dikembangkan di wilayah Indonesia, yakni bekerja sama dengan mitra-mitra lainnya. Secara sederhana dapat dipahami bahwa sistem ini terdiri dari kumpulan aplikasi yang dapat digunakan sebagai alat bantu dalam kegiatan pendidikan jarak jauh sehingga penyampaian materi pembelajaran jarak jauh ini adalah teknologi informasi. Kemunculan teknologi informasi dan komunikasi pada pendidikan jarak jauh sangat membantu. Seperti dapat dilihat dengan munculnya berbagai pendidikan secara online, baik pendidikan formal atau nonformal, dengan menggunakan fasilitas internet. Pendekatan sistem pengajaran yang dapat dilakukan adalah dengan melakukan pengajaran secara langsung (real time) atau pun dengan cara menggunakan sistem sebagai tempat pemusatan pengetahuan (knowledge). Hal ini memungkinkan terbentuknya kesempatan bagi siapa saja untuk mengikuti jenjang pendidikan. Seorang lulusan sarjana dapat melanjutkan ke pendidikan magister secara online pada salah satu perpendidikan tinggi yang diminatinya. ${ }^{17}$

c. Karakteristik Pembelajaran Jarak Jauh 
http://jurnalsttn.ac.id/index.php/SJT

p-ISSN 2772-3078, e-ISSN 2772-306X
Sekolah Tinggi Teologi Nusantara, Salatiga

Edisi: Volume 2, Nomor 2, November 2021

Sistem pembelajaran jarak jauh mempunyai karakteristik yang berbeda dengan praktik pembelajaran konvensional secara tatap muka. Menurut Keegan (1980) sistem pembelajaran jarak jauh memiliki karakteristik, yaitu: 1) pemisahan antar pendidik dengan pesera didik, 2) pengaruh institusi/organisasi Pendidikan, 3) penggunaan media yang menghubungkan pendidik dengan peserta didik, 4) berlangsungnya komunikasi dua arah, 5) memperhatikan pembelajarar sebagai individu yang perlu belajar, dan 6) pendidik sebagai suatu industry. Hal yang sama juga diungkapkan oleh Wasrita Bambang, sebagai berikut:

1) Adanya keterpisahan yang mendekati permanen antar tenaga pendidik dari peserta didik selama program Pendidikan.

2) Pemanfaatan saran komunikasi baik mekanis maupun elektronis untuk menyampaikan bahan pembelajaran.

3) Penyediaan sara komunikasi dua arah sehingga peserta didik dapat mengambil inisiatif dialog dan dan mengambil manfaatnya. 18

Berikut ini peneliti memaparkan beberapa karakteristik pembelajaran jarak jauh yang diselenggarakan di Sekolah Tinggi Teologi Kristus Alfa Omega, semarang, yaitu:

\section{Media dalam Pembelajaran Jarak jauh}

Pelaksanaan pembelajaran jarak jauh membutuhkan media pembelajaran tepat yang harus diseuaikan dengan situasi dan kondisi materi pembelajaran sehingga dapat digunakan secara maksimal. Dalam penggunaan media pembelajaran juga diperlukan kemampuan literasi digital agar efektivitas pembelajaran dapat tercapai dengan baik. Kemampuan tersebut berupa kemampuan dalam menggunakan teknologi dan informasi. Media yang digunakan dalam pembelajaran jarak jauh di antaranya, yaitu:

a) Media berbantuan komputer 
http://jurnalsttn.ac.id/index.php/SJT

p-ISSN 2772-3078, e-ISSN 2772-306X
Sekolah Tinggi Teologi Nusantara, Salatiga

Edisi: Volume 2, Nomor 2, November 2021

Tersedia banyak media atau platform pembelajaran berbasis teknologi yang jauh sebelum Pandemi Covid-19, sudah digunakan hanya mungkin belum maksimal, mengingat proses pembelajaran berlangsung secara konvensional. Beberapa Platform tersebut terbilang efektif dan efisien dalam pengaplikasiannya karena mudah diakses serta free (tidak membutuhkan iuran akses berlangganan, hanya membutuhkan kuota) meliputi google suite (google drive, google form, google site dan google classroom), Edmodo, Schooly, Lark suite, Kelas Maya dari rumah belajar, email dan media video conference (webex, zoom, google meet, telegram bahkan yang paling sederhana yaitu whats app). Berbagai media sosial yang banyak minati oleh kamu milenial pundapat digunakan dalam proses pembelajaran online seperti facebook dan Instagram. ${ }^{19}$ Berikut ini pembahasannya:

\section{1) E-leraning}

Paradigma baru yang muncul terkait dengan proses pembelajaran Jarak Jauh (PJJ) yang tidak lagi menggambarkan pertemuan tatap muka di dalam kelas telah diterima secara luas dan mempengaruhi pada bidang Pendidikan teruma pada masa pandemic Covid-19 ini, meskipun konsep interaksi sosial di dalamnya tetap dipertahankan. E-learning menjadi pilihan dan merupakan sumber belajar dalam menghadapi tantangan masa depan sekaligus merespon pandemic Covid-19. Melalui E-learning, proses pembelajaran dapat berlangsung di mana pun dan tidak perlu lagi tatap muka di kelas. ${ }^{20}$

Dalam pembelajaran jarang jauh yang dilakukan secara daring ini ada dua istilah yang harus dipahami secara tepat, yaitu; synchronius dan asynchronous. Secara sepintas kedua istilah ini tidak memiliki perbedaan yang mencolok, karena

${ }^{19}$ Dkk Gusti, Sri, Belajar Mandiri: Pembelajaran Daring Di Tengah Pandemi, Yayasan Kita Menulis, vol. 4 (Kita Menulis, 2020), http://marefateadyan.nashriyat.ir/node/150, 2.

${ }^{20}$ Tri Darmayanti, Made Yudhi Setiani, and Boedhi Oetojo, "E-Learning Pada Pendidikan Jarak Jauh: Konsep Yang Mengubah Metode Pembelajaran Di Perguruan Tinggi Di Indonesia," Jurnal Pendidikan Terbuka Dan Jarak Jauh 8, no. 2 (2007): 99-113, http://jurnal.ut.ac.id/index.php/jptjj/article/view/538, 100. 
http://jurnalsttn.ac.id/index.php/SJT

p-ISSN 2772-3078, e-ISSN 2772-306X
Sekolah Tinggi Teologi Nusantara, Salatiga

Edisi: Volume 2, Nomor 2, November 2021

kedianya merupakan pembelajaran dengan audio viede based dan multiple modalities. Namun bila dicermati, ada perbedaan yang cukup besar di antara keduaanya. Pembelajaran synchronous mengharuskan pelaku yang telibat dalam pemberajaran berada pada waktu yang sama meski berada pada tempat yang berbeda. Sistem ini bisa dilakukan melalui video call atau pertemuan dengan menggunakan aplikasi, seperti zoom, googel meeting dan lain-lain. Tetapi jika asynchronous memungkinkan pelaku pembelajaran berada diwaktu dan tempat yang berbeda. Dalam arti proses pembelajaran tidak dilaksanakan melalui interaksi tatap muka secara virtual. Berikut ini beberapa perbedaan mendasar antara synchronous dan asyinchronous, yaitu: ${ }^{21}$

\begin{tabular}{|l|l|}
\hline Synchronous & Asyinchronous \\
\hline $\begin{array}{l}\text { Dilaksanakan pada waktu yang } \\
\text { sama, tapi di tempat yang } \\
\text { berbeda }\end{array}$ & $\begin{array}{l}\text { Dilaksanakan pada waktu dan } \\
\text { tempat yang berbeda }\end{array}$ \\
\hline $\begin{array}{l}\text { Pendidik dan peserta didik } \\
\text { melaksanakan pembelajaran } \\
\text { pada waktu yang bersamaan }\end{array}$ & $\begin{array}{l}\text { Peserta didik dibebaskan dalam } \\
\text { menyelesaikan tugas dengan tepat } \\
\text { waktu }\end{array}$ \\
\hline $\begin{array}{l}\text { Adanya interaksi antara } \\
\text { pendidik dengan peserta didik }\end{array}$ & $\begin{array}{l}\text { Peserta didik mengerjakan tugas } \\
\text { secara mandiri }\end{array}$ \\
\hline $\begin{array}{l}\text { Metode yang digunakan dapat } \\
\text { berupa konferensi video atau } \\
\text { online chat room }\end{array}$ & $\begin{array}{l}\text { Metode yang digunakan bisa } \\
\text { dengan membaca, mendengarkan } \\
\text { atau menonton berbagai konten } \\
\text { video yang terkait dengan materi } \\
\text { pembelajaran. }\end{array}$ \\
\hline
\end{tabular}

${ }^{21}$ Robert Bala, Cara Mengajar Kreatif Pembelajaran Jarak Jauh (Jakarta, 2021), 5. 
http://jurnalsttn.ac.id/index.php/SJT

p-ISSN 2772-3078, e-ISSN 2772-306X
Sekolah Tinggi Teologi Nusantara, Salatiga

Edisi: Volume 2, Nomor 2, November 2021

Kedua jenis kegiatan pembelajaran di atas digunakan dalam pelaksannan pembelajaran jarak jauh yang diselenggarakan di Sekolah Tinggi teologi Kristus Alfa Omega Semarang.

2) Aplikasi Zoom

Pembelajaran Jarak Jauh dengan menggunakan zoom sebagai alternatif media yang digunakan mampu mempermudah dalam pelaksanaan karena pembelajaran dilakukan secara serentak dan bersama-sama dalam tempat yang berbeda, sehingga memberikan efesiensi waktu baik untuk pendidik ataupun peserta didik. Zoom sebagai video conferencing banyak digunakan oleh berbagai kalangan, sebab Zoom menyediakan video konferensi yang dapat dijangkau oleh seluruh partisipan selain rekaman video juga memiliki fitur chatting sehingga jika ada yang mendapatkan kurang pendengaran maka dapat berbicara melalui chatting. ${ }^{22}$

\section{3) Google Meeting}

Google meet juga merupakan platform berbasai video conference atau tatap muka yang memungkinkan terjadinya interaksi antara pendidik dengan peserta didik seperti bertemu secara langsung. Google mengeluarkan google meet yang memungkinkan penguna untuk melakukan panggilan video dengan 25 pengguna lainnya oer pertemuan. Dengan kata lain, google meet bisa menjdai media alternatif untuk proses belajar mengajar, bersisoalisasi.

Google meet dapat digunakan secara gratis untuk skala kecil sebanyak 25 orang. Dengan banyaknya orang yang juga berselancar dan melakukan pekerjaan secara online turt mengganggu kelancaran konferensi online. Google meet memiliki interface atau antar muka yang unik dan fungsional dengan ukuran ringan serta

\footnotetext{
22 Ismail Akbar Brahma, "Penggunaan Zoom Sebagai Pembelajaran Berbasis Online Dalam Mata Kuliah Sosiologi Dan Antropologi Pada Mahasiswa PPKN Di STKIP Kusumanegara Jakarta," Aksara: Jurnal Ilmu Pendidikan Nonformal 6, no. 2 (2020): 98.
} 


\section{Sabda: Jurnal Teologi Kristen}

http://jurnalsttn.ac.id/index.php/SJT

p-ISSN 2772-3078, e-ISSN 2772-306X
Sekolah Tinggi Teologi Nusantara, Salatiga

Edisi: Volume 2, Nomor 2, November 2021

cepat, mengedepankan pengelolaan yang efisien, mudah guna yang dapat diikuti semua pesertanyaa. Integrasi antara google meet dan g suit akan memudahkan para pengguna dalam hal bergabung dalam video conference menggunakan kalender atau undangan yang dibagikan.

Menurur Sawitri, google meet memiliki kelebihan sebagai berikut:

1) Fitur White Board, fitur ini dapat memudahkan kita dalam membuat tulisan atau gambar yang membantu dalam proses menerangkan materi pelajaran kepada peserta didik.

2) Tersedia secara gratis, google meet dapat diunduh pada Playstore atau app store bagi pengguna ios.

3) Kualitas Video HD dan didukung dengan resolusi lain, dengan fitur ini tampilan dilayar akan menjadi lebih jernih.

4) Penggunaan yang mudah, Langkah agar dapat menggunakan googel meet adalah cukup dengan mendaftar menggunakan akun google pada aplikasinya.

5) Layanan Enkrpsi video, layanan ini memungkinkan terjaminnya data pengguna yang bersifat rahasia sehingga tidak akan disalahgunakan.

6) Banyak pilihan tampilan menarik, fitur ini memungkin pengguna untuk dapat mengatur tampilan pada video conference sesuai keinginan seprti tata letak yang pas dan baik.

7) Jumlah peserta yang dapat diundang mencapai 100 peserta, dengan berlangganan G suite maka dapat mengundang 100-250 peserta. Sedangkan jika menggunakn google meet versi free dapat menggundang 25 peserta.

Kelemahan dari goole meet adalah sebagai berikut:

1) Tidak ada fitur hemat data, google meet belum memiliki fitur untuk menghemat kuota sehingga selama panggilan berlangsung kemungkinan terburuk adalah terputusnya panggilan maupun kualitas audio dan video google meet yang tidak jelas hal ini disebabkan kerana penggunaan kuota internet yang boros. 


\section{Sabda: Jurnal Teologi Kristen}

http://jurnalsttn.ac.id/index.php/SJT

p-ISSN 2772-3078, e-ISSN 2772-306X
Sekolah Tinggi Teologi Nusantara, Salatiga

Edisi: Volume 2, Nomor 2, November 2021

2) Tidak semua fasilitas free, pengguna google meet dapat menikmati fitur yang lebih banyak dan lengkap apabila telah berlangganan dengan membeli paket google suite.

3) Membutuhkan jaringan internet yang stabil, selin perlu jaringan yang cepat, dalam hal akses google meet juga diperlukan konsi jaringan yang stabil sehingga google meet akan bekerja dengan semestinya tandpa adanya kendala.

\section{4) Youtube}

Youtube dinilai sebagai salah satu media yang memiliki potensi yang luar biasa yang dapat digunakan dalam peningkatan kulaitas pembelajaran jarak jauh. Youtube dapat memberikan peserta didik ataupun pendidik dalam hal kebebasan berekspresi, berkolaborasi di dalam dunia kependidikan, serta dapat memperoleh pengalaman berharga dalam meningkatkan kapabilitas peserta didik dan pendidik. Youtube dikenal sebagai situs berbasis visual yang paling familiar di seluruh dunia. Dengan Youtube seseorang dapat menonton, mengupload, dan berbagi video gratis. Kelebihan Youtube yaitu tersedia berbagai type video yang beranekara ragam yang dapat membantu menngatasi kendala-kendala yang dialami. ${ }^{23}$

\section{5) Media sosial whatsapp}

Whatsapp sebagai salah satu media sosial paling berpengaruh dan banyak digunakan oleh masyakarakat di Indonesia. Peserta didik di era ini juga sudah menggunakan aplikasi media sosial seperti Whatsapp, meskiupun pada awalnya digunakan untuk bermedia sosial saja, tetapi kini Whatsapp memberikan banyak

\footnotetext{
${ }^{23}$ Mochamad Rangga Mahendra, "Youtube Sebagai Media Pembelajaran," Vocational Education of Building Construction, University of Jakarta, Jakarta, last modified 2020, accessed July 16, 2020, https://www.researchgate.net/publication/341251703_Youtube_sebagai_Media_Pembelajaran.
} 


\section{Sabda: Jurnal Teologi Kristen}

http://jurnalsttn.ac.id/index.php/SJT

p-ISSN 2772-3078, e-ISSN 2772-306X
Sekolah Tinggi Teologi Nusantara, Salatiga

Edisi: Volume 2, Nomor 2, November 2021

manfaat lebih terutama untuk pelaksanaan Pembelajaran Jarak Jauh dengan meningkatnya kemampuan literasi digital. ${ }^{24}$

b) Menggunakan Media cetak

Media cetak digolongkan sebagai teknologi generasi pertama dalam sistem Pembelajaran Jarak Jauh. Hampir semua pembelajaran jarak jauh di dunia memanfaatkan media cetak sebagai media utama untuk menyampaikan materi ajar. Hal ini karena media cetak lebih bersifat flesibilitas tempat dalam arti dapat digunakan dimana saja. Flesikbilitas waktu dalam arti kapan saja, wujud (buku materi, buku kerja, panduan belajar, pamphlet, brosur, peta, chart), jenis cetakan (tulisan, gambar, foto, grafik, tabel) serta kemampuannyan untuk dipadukan dengan medua lain. ${ }^{25}$ Beberapa komponen penting dalam bahan ajar vetak, yaitu:

- Deskripsi materi ajar secara menyeluruh

- Tujuan Pembelajaran yang akan dicapai

- Manfaat dan relevansi materi ajar

- Contoh kompetensi yang akan dimiliki setelah pembelajaran

- Materi Ajar

- Latihan

- Umpan Balik. ${ }^{26}$

\section{Sistem Pembalajaran Jarak Jauh}

Sistem teknologi merupakan bagian integral dari pendidikan jarak jauh, namun program pendidikan harus fokus pada kebutuhan instruksional peserta didik daripada

\footnotetext{
${ }^{24}$ Muhammad Wildan Sahidillah and Prarasto Miftahurrisqi, "Whatsapp Sebagai Media Literasi Digital Siswa," Jurnal VARIDIKA 1, no. 1 (2019): 52-57.

${ }^{25}$ M Tubagus and S Kom, Model Pembelajaran Terbuka Jarak Jauh: Kajian Teoritis Dan Inovasi (Yoyakarta: Mesia Pustaka, 2021), https:/ / books.google.com/books?hl=en\&lr=\&id=LXEyEAAAQBAJ\&oi=fnd\&pg=PA1\&dq=tpack+pembe lajaran+daring\&ots=J2FPUYhOOC\&sig=ZsZn8G7EXidorNqCx51AfNck56I.

${ }^{26} \mathrm{Ibid}, 29-30$.
} 
http://jurnalsttn.ac.id/index.php/SJT

p-ISSN 2772-3078, e-ISSN 2772-306X
Sekolah Tinggi Teologi Nusantara, Salatiga

Edisi: Volume 2, Nomor 2, November 2021

teknologinya sendiri. Selain itu, perlu juga mempertimbangkan umur, kultur, latar belakang sosial ekonomi, interes, pengalaman, level pendidikan, dan terbiasa atau tidak dengan metode jarak jauh. Faktor yang penting untuk keberhasilan sistem pendidikan jarak jauh adalah perhatian, percaya diri pengajar, pengalaman, mudah menggunakan peralatan, kreatif menggunakan alat dan menjalin interaksi dengan peserta didik.

Pada pembangunan sistem perlu diperhatikan tentang desain dan pengembangan sistem, interactivity, active learning, visual imagery, dan komunikasi yang efektif.

a. Desain dan pengembangan sistem. Proses pengembangan instruksional untuk pendidikan jarak jauh terdiri dari tahap perancangan, pengembangan, evaluasi, dan revisi. Dalam mendesain intruksi pendidikan jarak jauh yang efektif, harus diperhatikan, tidak saja tujuan, kebutuhan, dan karakteristik pendidik dan peserta didik, tetapi juga kebutuhan isi dan hambatan teknis yang mungkin terjadi. Revisi dilakukan berdasarkan masukan dari instruktur, spesialis pembuat isi, dan peserta didik selama dalam proses pembelajaran berlangsung.

b. Interactivity. Keberhasilan sistem pendidikan jarak jauh antara lain ditentukan oleh adanya interaksi antara pendidik dan peserta didik, antara peserta didik dan lingkungan pendidikan, dan antara peserta didik dengan peserta didik lainnya.

c. Active learning. Partisipasi aktif peserta didik jarak jauh mempengaruhi cara bagaimana mereka berhubungan dengan materi yang akan dipelajari.

d. Visual imagery. Pembelajaran melalui televisi dapat memotivasi dan merangsang keinginan dalam proses pembelajaran. Namun, jangan sampai terjadi distorsi karena adanya hiburan. Harus ada penyeleksian antara informasi yang tidak berguna dengan yang berkualitas, menentukan mana yang layak dan tidak, mengidentifikasi penyimpanan, membedakan fakta dari yang bukan fakta, dan mengerti bagaimana teknologi dapat memberikan informasi yang berkualitas. 
http://jurnalsttn.ac.id/index.php/SJT

p-ISSN 2772-3078, e-ISSN 2772-306X
Sekolah Tinggi Teologi Nusantara, Salatiga

Edisi: Volume 2, Nomor 2, November 2021

e. Komunikasi yang efektif. Desain instruksional dimulai dengan mengerti harapan pemakaian, dan mengenal mereka sebagai individu yang mempunyai pandangan berbeda dengan perancang sistem. Dengan memahami keinginan pemakai maka dapat dibangun komunikasi yang efektif. ${ }^{27}$

\section{Pendidikan Jarak Jauh secara Online}

Perkembangan teknologi selalu mempunyai peran yang sangat tinggi dan ikut memberikan arah perkembangan dunia pendidikan. Dalam sejarah perkembangan pendidikan, teknologi informasi adalah bagian dari media yang digunakan untuk menyampaikan pesan ilmu pada banyak orang, mulai dari teknologi percetakan beberapa abad yang lalu, seperti buku yang dicetak hingga media telekomunikasi, seperti suara yang direkam pada kaset, video, televisi, dan CD.

Perkembangan teknologi informasi saat ini internet mengarahkan sejarah teknologi pendidikan pada alur yang baru. Layanan online dalam pendidikan baik bergelar maupun tidak bergelar pada dasarnya adalah memberikan pelayanan pendidikan bagi pengguna (peserta didik) dengan menggunakan internet sebagai media. Layanan online ini dapat terdiri atas berbagai tahapan dari proses program pendidikan, seperti pendaftaran, tes masuk, pembayaran, perkuliahan, penugasan kasus, pembahasan kasus, ujian, penilaian, diskusi, pengumuman, dan lain-lain. Pendidikan jarak jauh dapat memanfaatkan teknologi internet secara maksimal sehingga memberikan efektivitas dalam hal waktu, tempat, bahkan meningkatkan kualitas pendidikan.

Faktor utama dalam pendidikan jarak jauh secara online dikenal sebagai distance learning, yang selama ini dianggap masalah adalah tidak adanya interaksi antara pendidik dengan peserta didik. Namun demikian, dengan media internet sangat dimungkinkan untuk melakukan interaksi antara pendidik dengan peserta didik baik 


\section{Sabda: Jurnal Teologi Kristen}

http://jurnalsttn.ac.id/index.php/SJT

p-ISSN 2772-3078, e-ISSN 2772-306X
Sekolah Tinggi Teologi Nusantara, Salatiga

Edisi: Volume 2, Nomor 2, November 2021

dalam bentuk real time (waktu nyata) atau tidak. Dalam bentuk real time dapat dilakukan misalnya dalam suatu chatroom, interaksi langsung dengan real audio atau real video, dan online meeting. Sedangkan untuk yang tidak real time bisa dilakukan melalui mailing list, discussion group, newsgroup, dan bulletin board.

Pendidikan jarak jauh secara online mengatasi keterbatasan yang ada pada jenis-jenis pendidikan jarak jauh yang lain (yang sebenarnya juga sudah sarat teknologi), yaitu pendidikan jarak jauh dengan satelit serta teknologi televisi. Pada kedua teknologi di atas, peserta didik dapat belajar sendiri dari rumah dengan peralatan computer sendiri.

1. Sudut pandang pendidik

Dari sudut pandang dosen, solusi pendidikan online harus memenuhi beberapa kriteria sebagai berikut: mudah digunakan, memungkinkan pembuatan bahan kuliah online dan kelas online dengan cepat dan mudah, hanya memerlukan pelatihan minimal, memungkinkan pengajaran dengan cara mereka sendiri, memungkinkan mereka mengendalikan lingkungan pembelajaran.

2. Sudut pandang peserta didik

Dari sudut peserta didik yang dicari adalah fleksibilitas dalam mengambil mata kuliah. Bahan kuliah yang didapat secara online lebih kaya dibandingkan yang di depan kelas. Berjalan di komputer yang mereka miliki. Menyertakan kolaborasi antar peserta didik secara tradisional, mencakup konsultasi dengan pendidik, diskusi kelas, teman belajar, dan proyek-proyek bersama. ${ }^{28}$

\section{Pendidikan Jarak Jauh Berbasis Web secara Online}


http://jurnalsttn.ac.id/index.php/SJT

p-ISSN 2772-3078, e-ISSN 2772-306X
Sekolah Tinggi Teologi Nusantara, Salatiga

Edisi: Volume 2, Nomor 2, November 2021

Ada beberapa unsur yang perlu diperhatikan dalam pendidikan jarak jauh berbasis web, yaitu:

1. Pusat kegiatan peserta didik; sebagai suatu community web based distance learning harus mampu menjadikan sarana ini sebagai tempat kegiatan peserta didik, di mana mereka dapat menambah kemampuan, membaca materi pembelajaran, mencari informasi dan sebagainya.

2. Interaksi dalam group; para peserta didik dapat berinteraksi satu sama lain untuk mendiskusikan materi-materi yang diberikan. Pendidik pun dapat hadir dalam group ini untuk memberikan sedikit ulasan tentang materi yang diberikan.

3. Sistem adminstrasi peserta didik; di mana mereka dapat melihat informasi mengenai statusnya, prestasinya dan lain-lain.

4. Pengalaman materi dan ujian; biasanya pendidik mengadakan kuis singkat dan tugas yang bertujuan untuk pendalaman dari apa yang telah diajarkan serta melakukan tes pada akhir masa belajar. Hal ini juga harus dapat diantisipasi oleh web based distance learning.

5. Perpustakaan digital; pada bagian ini terdapat berbagai informasi kepustakaan, tidak terbatas pada buku, tetapi juga ada kepustaakn digital seperti suara, gambar dan sebagainya. Bagian ini bersifat sebagai penunjang dan berbentuk data base.

6. Materi online di luar mata kuliah; untuk menunjang perkuliahan, diperlukan juga bahan bacaan web lain. Oleh karena itu, pada bagian ini pendidik dan peserta didik dapat langsung terlibat untuk memberikan bahan lainnya untuk dipublikasikan kepada peserta didik lainnya melalui web. Mewujudkan ide dan keinginan di atas dalam bentuk realitas bukanlah pekerjaan yang mudah, tetapi apabila kita lihat ke negara lain yang telah lama mengembangkan web based distance learning, sudah banyak institusi atau lembaga memanfaatkan metode ini. 29

${ }^{29} \mathrm{Ibid}, 39-40$. 
http://jurnalsttn.ac.id/index.php/SJT

p-ISSN 2772-3078, e-ISSN 2772-306X
Sekolah Tinggi Teologi Nusantara, Salatiga

Edisi: Volume 2, Nomor 2, November 2021

\section{Hasil Penelitian}

Hasil penelitian merupakan berdasarkan hasil uji hipotesis. Adapun bunyi rumusan hipotesisnya adalah sebagai berikut:

$\mathrm{H}_{\mathrm{o}} \quad$ : Diduga efektivitas model pembelajaran jarak jauh di Sekolah Tinggi Teologogi

Kristus Alfa Omega Semarang Tahun 2021 berada dalam kategori sedang atau $\geq$ $60 \%$.

$\mathrm{H}_{\mathrm{a}} \quad$ : Diduga efektivitas model pembelajaran jarak jauh di Sekolah Tinggi Teologogi

Kristus Alfa Omega Semarang Tahun 2021 tidak berada dalam kategori efektif atau $<60 \%$.

Analisis uji hipotesis dalam penelitian ini menggunakan uji $t$ test satu sampel dengan SPSS 25, sebab dalam penelitian dilakukan pengambilan sampel. Uji $t$ test adalah uji hipotesis deskriptif yang hasilnya dapat digeneralisasikan pada populasi, sebab uji t test juga merupakan uji signifikansi. Adapun ketentuan uji hipotesis deskriptif dengan menggunakan $t$ test yang merupakan uji satu pihak yaitu pihak kiri adalah sebagai berikut; Jika $-\mathrm{t}$ tabel $\leq \mathrm{t}$ hitung maka Ho diterima dan Ha ditolak dan jika $-\mathrm{t}$ tabel $>t$ hitung maka Ho ditolak dan Ha diterima. ${ }^{30}$

\begin{tabular}{|r|r|r|r|c|}
\hline \multicolumn{5}{|c|}{ One-Sample Statistics } \\
\hline & \multicolumn{1}{|c|}{$\mathrm{N}$} & Mean & $\begin{array}{c}\text { Std. } \\
\text { Deviation }\end{array}$ & $\begin{array}{c}\text { Std. Error } \\
\text { Mean }\end{array}$ \\
\hline Total & 104 & 103.66 & 9.332 & .915 \\
\hline
\end{tabular}

\begin{tabular}{|l|r|}
\hline \multicolumn{2}{|c|}{ One-Sample Test } \\
\hline & Test Value $=60$ \\
\hline
\end{tabular}

${ }^{30}$ Sofyan Siregar, Statistik Parametrik Untuk Penelitian Kuantitatif: Dengan Dilengkapi Perhitungan Manual Dan Aplikasi SPSS Versi 17, Jakarta : Kencana (Jakarta: RAJAWALI PRESS, 2013), 199. 


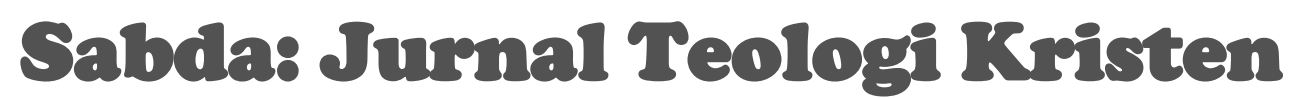

http://jurnalsttn.ac.id/index.php/SJT

p-ISSN 2772-3078, e-ISSN 2772-306X
Sekolah Tinggi Teologi Nusantara, Salatiga

Edisi: Volume 2, Nomor 2, November 2021

\begin{tabular}{|c|c|c|c|c|c|c|}
\hline & \multirow[b]{2}{*}{$\mathrm{T}$} & \multirow[b]{2}{*}{ Df } & \multirow{2}{*}{$\begin{array}{l}\text { Sig. (2- } \\
\text { tailed) }\end{array}$} & \multirow{2}{*}{$\begin{array}{c}\text { Mean } \\
\text { Difference }\end{array}$} & \multicolumn{2}{|c|}{$\begin{array}{l}\text { 95\% Confidence Interval } \\
\text { of the Difference }\end{array}$} \\
\hline & & & & & Lower & Upper \\
\hline Total & 47.717 & 103 & .000 & 43.663 & 41.85 & 45.48 \\
\hline
\end{tabular}

Tabel 4.7

Uji T Test Satu Sampel

Berdasarkan table di atas diketahui bahwa nilai t hitung adalah 47,717 sedangkan nilai $\mathrm{t}$ table didapatkan dengan melihat daftar table $\mathrm{T}$ pada derajat kebebasan (df- degree of freedom) 103 dengan taraf kesalahan 5\% sebesar 1,645. Langkah selanjutnya adalah memperhatikan ketentuna uji pihak kiri: Jika $-t_{t a b e l} \leq t$ hitung maka Ho diterima dan Ha ditolak dan jika $-\mathrm{t}$ tabel $>\mathrm{t}$ hitung maka Ho ditolak dan Ha diterima. ${ }^{31}$ Berdasarkan nilai $t$ hitung dan $t$ tabel di atas maka diperoleh nilai $-t_{\text {tabel }}(-1,645) \leq t$ hitung (47,717) maka hipotesis Ho diterima dan Ha ditolak, sehingga bunyi Ho: diduga efektivitas model pembelajaran jarak jauh di Sekolah Tinggi Teologogi Kristus Alfa Omega Semarang Tahun 2021 berada dalam kategori efektif atau $\geq 60 \%$ diterima. Dan Ha yang berbunyi Diduga efektivitas model pembelajaran jarak jauh di Sekolah Tinggi Teologogi Kristus Alfa Omega Semarang Tahun 2021 tidak berada dalam kategori efektif atau $>60 \%$ ditolak.

Selanjutnya dilakukan penghitungan tentang seberapa besar nilai efektivitas model pembelajaran jarak jauh di Sekolah Tinggi Teologogi Kristus Alfa Omega Semarang Tahun 2021? Untuk mengetahui besaran tersebut, maka dilakukan penghitungan dengan rumus sebagai berikut: 32

${ }^{31}$ Ibid, 199.

32Sugiyono, Metode Penelitian Manajemen (Bandung: CV. Alfabeta, 2014), 277. 
http://jurnalsttn.ac.id/index.php/SJT

p-ISSN 2772-3078, e-ISSN 2772-306X
Sekolah Tinggi Teologi Nusantara, Salatiga

Edisi: Volume 2, Nomor 2, November 2021

\section{Harga $\%$ Variabel $X=\frac{\Sigma \text { Skor Empiris }}{\Sigma \text { Skor }} \times 100 \%$ $\Sigma$ Skor ldeal}

\section{Keterangan:}

Total skor empiris $\quad=$ Skor total data variabel $X=10781$

Total skor ideal $\quad=($ skor tertinggi tiap item $) \times($ jumlah item variabel $\mathrm{X})$

$x($ jumlah responden $)=5 \times 24 \times 104=12480$

Harga \% Variabel X $=(10781: 12480) \times 100 \%$

$$
=86,38 \%
$$

Jadi dapat disimpulkan bahwa nilai variabel model pembelajaran di Sekolah Tinggi

Teologi Kristus Alfa Omega Semarang adalah 86,38\%. Jika membuat interval interpretasi seperti yang dilakukan oleh Sugiyono, yaitu dari 0\% - 100\% adalah sebagai berikut:

\begin{tabular}{|l|l|}
\hline Prosentase & Interpretasi \\
\hline $0-20 \%$ & Sangat Tidak Efektif \\
\hline $21-40 \%$ & Tidak Efektif \\
\hline $41-60 \%$ & Sedang \\
\hline $61-80 \%$ & Efektif \\
\hline $\mathbf{8 1 - 1 0 0 \%}$ & Sangat Efektif \\
\hline
\end{tabular}

Tabel 4.8

Pedoman untuk interpretasi makna prosentasi deskriptif108

Maka dapat diintepretasikan bahwa nilai model pembelajaran di Sekolah Tinggi Teologi Kristus Alfa Omega Semarang 86,38\% dalam kategori sangat tinggi (81\%-100\%).

${ }^{108}$ Gideon Joshua, Penelitian Terhadap Hubungan Presepsi Gembala Sidang Tentang Pemimpin Hamba Dengan Keberhasilan Memimpin Gereja Lokal, Shift Key: Jurnal Teologi Dan Pelayanan (Semarang, 2009), 113. 
http://jurnalsttn.ac.id/index.php/SJT

p-ISSN 2772-3078, e-ISSN 2772-306X
Sekolah Tinggi Teologi Nusantara, Salatiga

Edisi: Volume 2, Nomor 2, November 2021

Hasil uji hipotesis ini juga didukung dengan data tambahan merupakan data yang peneliti peroleh dari lapangan yang merupakan penilaian responden terhada efektifitas model pembelajaran jarak jauh yang diselenggarakan di Sekolah Tinggi Teologi Kristus Alfa Omega Semarang. Penilaian ini meliputi; penilaian efektifitas model pembelajaran jarak jauh, kelebihan model pembelajaran jarak jauh, hambatan dalam pembelajaran jarak jauh, dan kelas yang direkomendasikan untuk menerapkan model pembelajaran jarak jauh. Adapun hasilnya sebagai berikut:

1. Penilaian efektivitas model pembelajaran jarak jauh di Sekolah Tinggi Teologi Kristus Alfa Omega Semarang Tahun 2021.

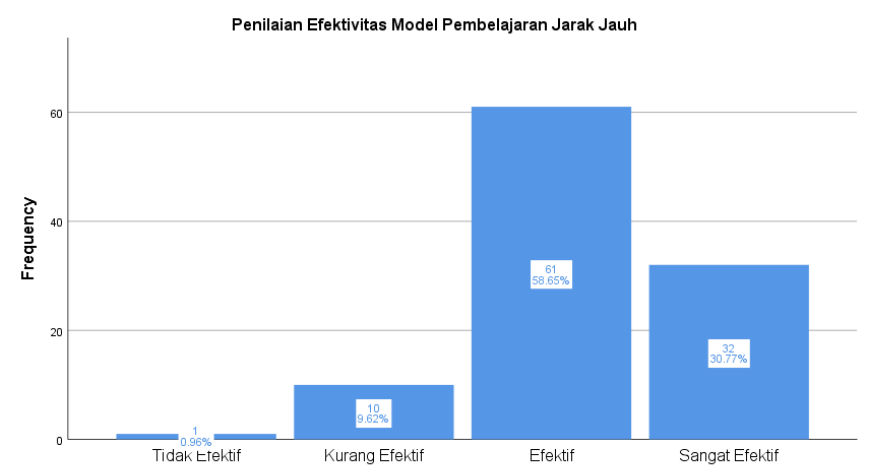

Tabel 4.29

Penilaian Efektivitas Model PJJ

Berdasarkan gambar 4.29 di atas dieproleh data dari 134 responden yang menyatakan sangat efektif sebanyak 32 atau 30,77\%, yang menyatakan efektif sebanyak 61 atau 58,65\%, yang menyatakan kurang efektif sebanyak 10 atau 9,62\%, dan yang menyatakan kurang efektif sebanyak 1 atau $0,96 \%$. Berdasarkan data ini maka dapat disimpulkan bahwa sebagian besar yaitu 93 atau 89,42\% responden menyatakan bahwa model pembelajaran jarak jauh di STT Kristus Alfa Omega tahun 2021 efektif. 
http://jurnalsttn.ac.id/index.php/SJT

p-ISSN 2772-3078, e-ISSN 2772-306X
Sekolah Tinggi Teologi Nusantara, Salatiga

Edisi: Volume 2, Nomor 2, November 2021

2. Kelebihan model pembelajaran Jarak jauh

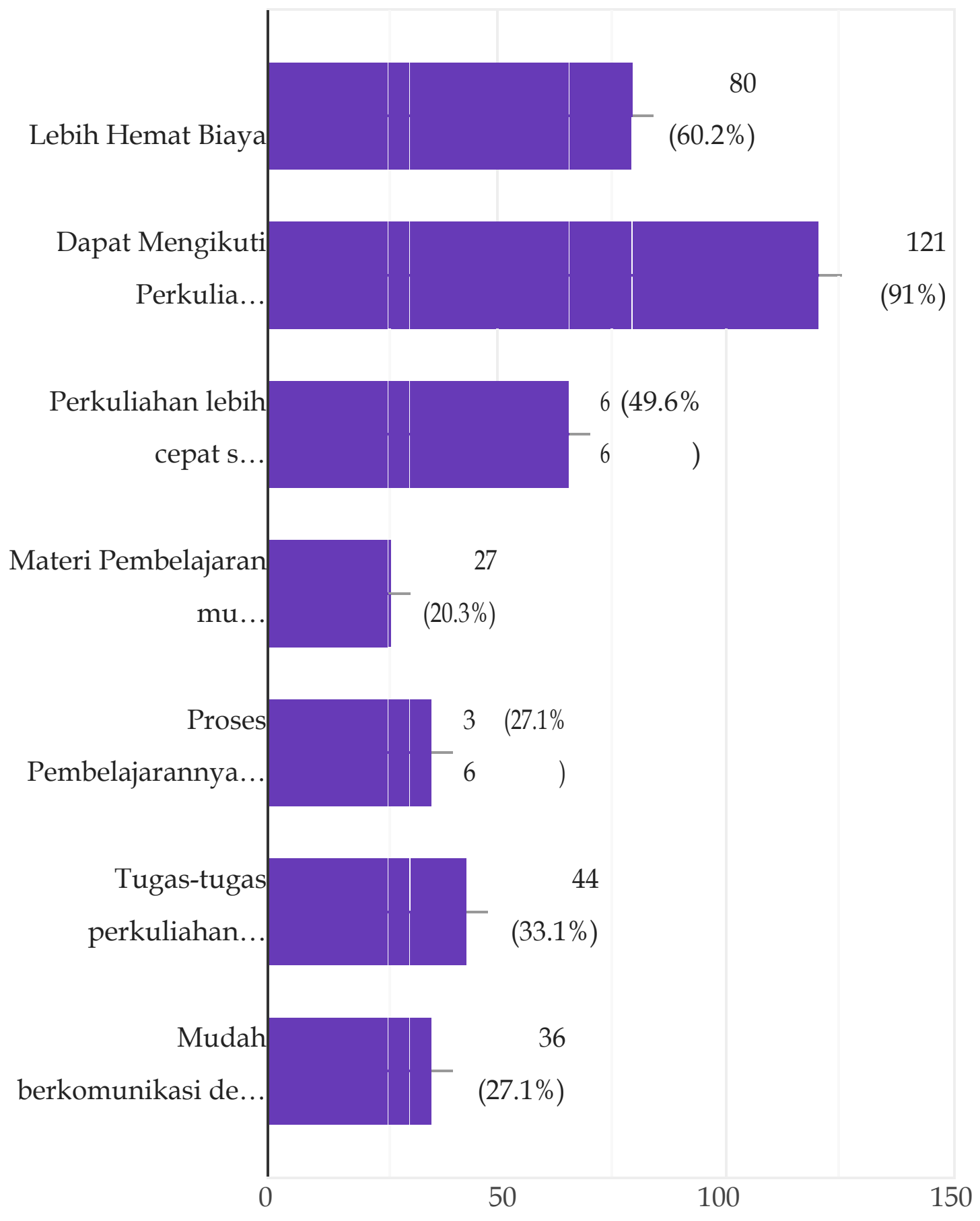

Gambar 4.30

Kelebihan Model Pembelajaran Jarak Jauh 
http://jurnalsttn.ac.id/index.php/SJT

p-ISSN 2772-3078, e-ISSN 2772-306X
Sekolah Tinggi Teologi Nusantara, Salatiga

Edisi: Volume 2, Nomor 2, November 2021

Berdasarkan berdasarkan gambar 4.29 di atas diperoleh data bahwa dari 134 responden yang menjadi sumber data dalam penelitian ini yang menyatakan dapat mengikuti perkuliahan tanpa harus meninggalkan tempat tinggal/pekerjaan/pelayanan sebanyak 121 (91\%), yang menyatakan model pembelajaran lebih hemat biaya sebanyak 80 atau $60 \%$, yang menyatakan perkulihan lebih cepat selesai sebanyak 66 atau 49,6\%, yang menyatakan tugas-tugas perkulihan yang proporsional sebanyak 44 atau 33,1\%, yang menyatakan proses pembelajarannya menyenangkan sebanyak 36 atau 27,1\%, yang menyatakan mudah berkomunikasi dengan dosen sebanyak 36 atau 33,1\%, dan yang terakhir adalah materi pembelajaran mudah dipahami sebanyak 27 atau 20,3\% .

3. Rekomendasi Kelas Untuk Pelaksanaan model pembelajaran jarak jauh

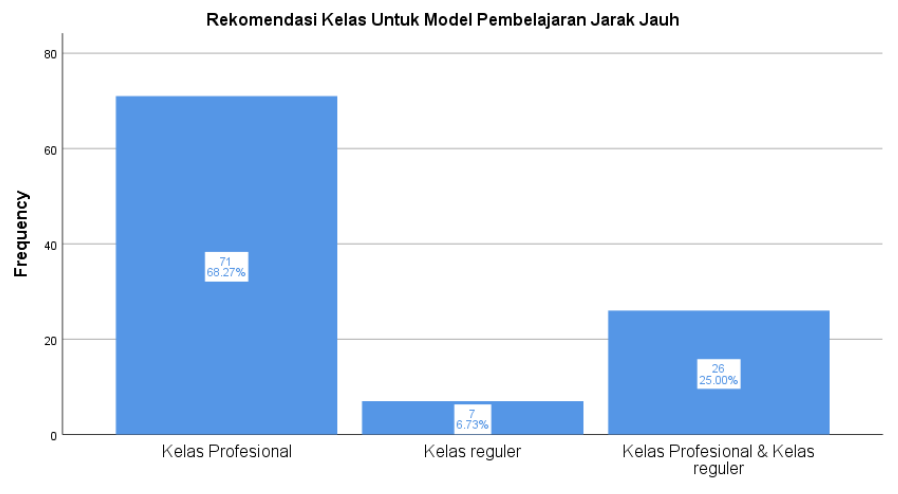

Tabel 4.31

Rekomendasi kelas untuk Penerapan Model PJJ

Berdasarkan tabel 4.31 di atas diperoleh data bahwa dari 104 responden yang merupakan mahasiswa STT Kristus Alfa Omega Semarang memberikan rekomendasi untuk pelaksanaan model pembelajaran jarak jauh sebagai berikut: Model pembelajaran jarak jauh direkomendasikan oleh 71 atau 68, 27\% dilaksanakan di kelas profesional, direkomendasikan oleh 26 atau 25\% dilaksanakan di kelas profesional dan kelas regular dan oleh 7 atau 6,73\% dilaksanakan di kelas regular. Berdasarkan data ini dapat 
http://jurnalsttn.ac.id/index.php/SJT

p-ISSN 2772-3078, e-ISSN 2772-306X
Sekolah Tinggi Teologi Nusantara, Salatiga

Edisi: Volume 2, Nomor 2, November 2021

disimpulkan bahwa Sebagian besar yaitu 97 atau 93,27\% yang merekomendasikan pelaksanaan model pembelajaran jarak jauh di kelas profesional Sekolah Tinggi Teologi Kristus Alfa Omega Semarang Tahun 2021. Hal ini sangat didukung dengan kelebihan model pembelajaran jauh bahwa mahasiswa dapat mengikuti proses perkuliahan tanpa harus meninggalkan tempat tinggal/pekerjaan/pelayanan di tempat masing-masing.

4. Hambatan dalam pelaksanaan Model Pembelajaran Jarak Jauh

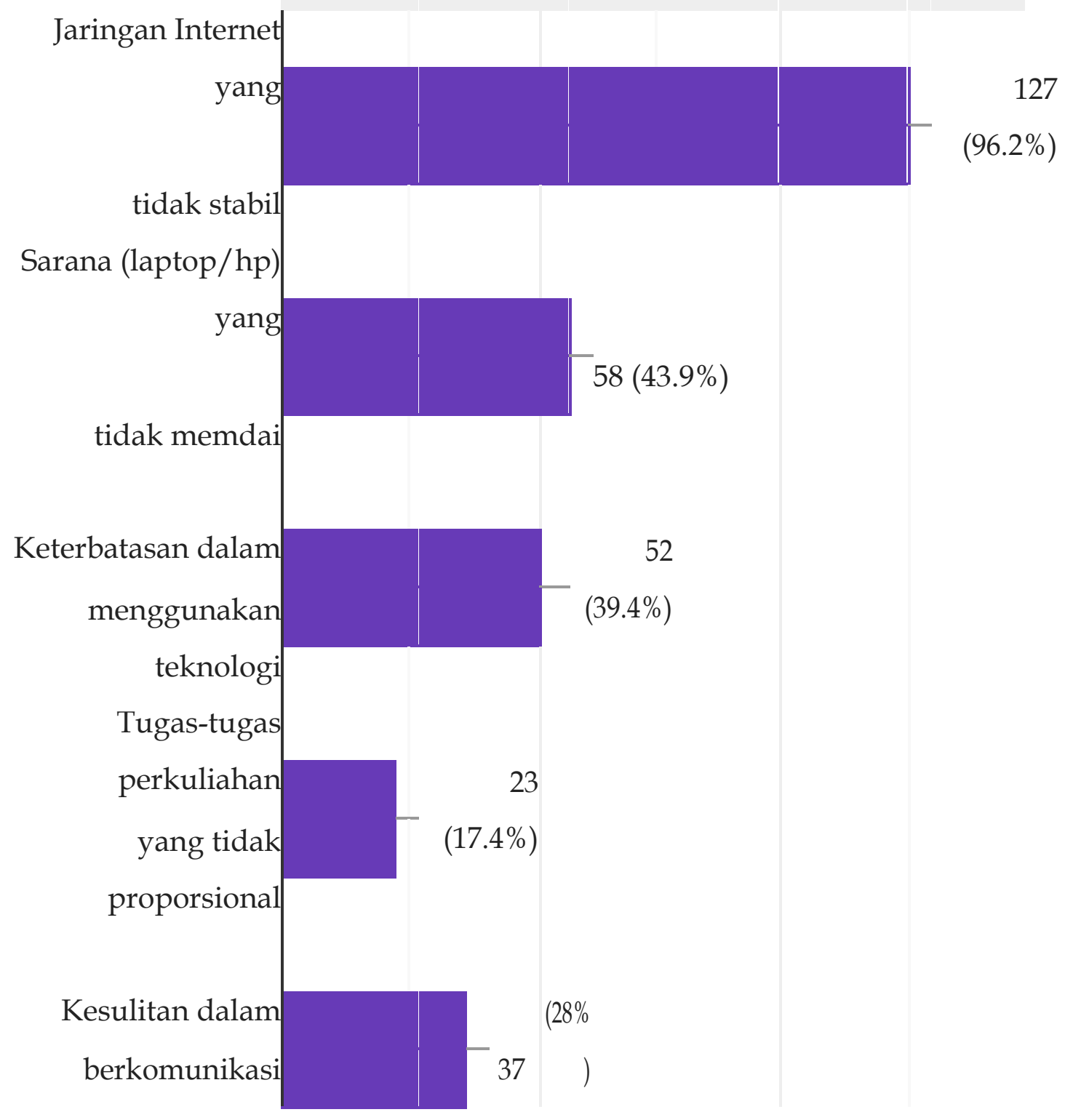


http://jurnalsttn.ac.id/index.php/SJT

p-ISSN 2772-3078, e-ISSN 2772-306X

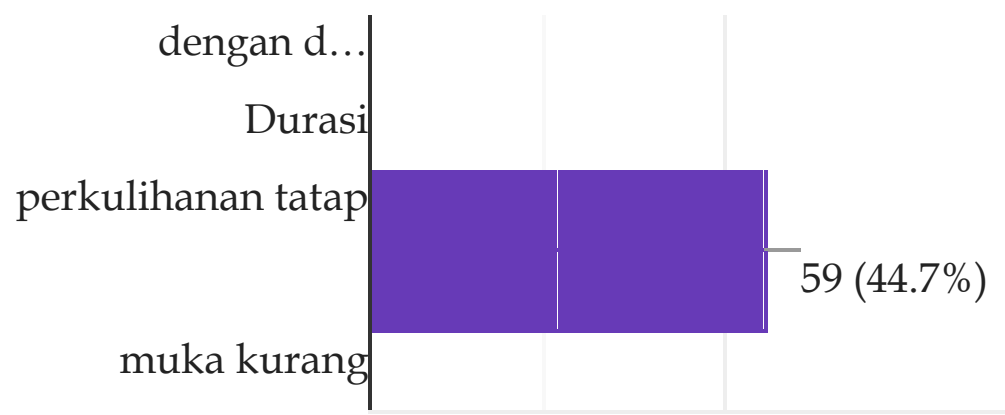

Gambar 4.32
Sekolah Tinggi Teologi Nusantara, Salatiga

Edisi: Volume 2, Nomor 2, November 2021

Hambatan dalam Model Pembelajaran Jarak Jauh

Berdasarkan tabel 4.32 tentang hambatan dalam model pembelajaran jarak jauh diperoleh data sebagai berikut: 1) hambatan yang paling banyak dialami oleh mahasiswa adalah jarungan internet yang tidak stabil sebanyak 127 atau 96,2\%, yang mengalami hambatan dalam hal durasi perkulihan tatap muka yang kurang sebanyak $59,44,7 \%$, yang mengalami hambatan dalam hal sarana (laptop/hp) yang tidak memadai sebanyak 58 atau 43,9\%, yang mengalami hambatan dalam keterbatasan menggunakan teknologi sebanyak 52 atau 39,4\%, yang mengalami hambatan dalam berkomunikasi dengan dosen sebanyak 37 atau 20\%, dan yang mengalami hambatan dalam tugas-tugas perkuliahan yang tidak proporsional sebanyak 23 atau 17,4\%. 
http://jurnalsttn.ac.id/index.php/SJT

p-ISSN 2772-3078, e-ISSN 2772-306X
Sekolah Tinggi Teologi Nusantara, Salatiga

Edisi: Volume 2, Nomor 2, November 2021

\section{Daftar Pustaka}

Ahmad Johari Sihes. Konsep Pembelajaran. E-Prints UTM. Yogyakarta: Gava Media, 2015. http:/ / repository.usu.ac.id/bitstream/123456789/23790/4/Chapter I.pdf.

Bala, Robert. Cara Mengajar Kreatif Pembelajaran Jarak Jauh. Jakarta, 2021.

Bambang, Warsita. Teknologi Pembelajaran: Landasan E Aplikasinya. Jakarta: Rineka, 2008.

Brahma, Ismail Akbar. “Penggunaan Zoom Sebagai Pembelajaran Berbasis Online Dalam Mata Kuliah Sosiologi Dan Antropologi Pada Mahasiswa PPKN Di STKIP Kusumanegara Jakarta." Aksara: Jurnal Ilmu Pendidikan Nonformal 6, no. 2 (2020): 98.

Darmayanti, Tri, Made Yudhi Setiani, and Boedhi Oetojo. “E-Learning Pada Pendidikan Jarak Jauh: Konsep Yang Mengubah Metode Pembelajaran Di Perguruan Tinggi Di Indonesia." Jurnal Pendidikan Terbuka Dan Jarak Jauh 8, no. 2 (2007): 99-113.

http:/ /jurnal.ut.ac.id/index.php/jptjj/article/view/538.

Gusti, Sri, Dkk. Belajar Mandiri: Pembelajaran Daring Di Tengah Pandemi. Yayasan Kita Menulis. Vol. 4. Kita Menulis, 2020. http:/ / marefateadyan.nashriyat.ir/node/150. Joshua, Gideon. Penelitian Terhadap Hubungan Presepsi Gembala Sidang Tentang Pemimpin Hamba Dengan Keberhasilan Memimpin Gereja Lokal. Shift Key : Jurnal Teologi Dan Pelayanan. Semarang, 2009.

Mahendra, Mochamad Rangga. "Youtube Sebagai Media Pembelajaran." Vocational Education of Building Construction, University of Jakarta, Jakarta. Last modified 2020. Accessed July 16, 2020. https://www.researchgate.net/publication/341251703_Youtube_sebagai_Media_P embelajaran.

Peraturan Pemerintah RI. Pasal 1 Ayat 2 \& 3 Undang-Undang Nomor 20 Tahun 2003, 2003. - - - Undang Undang Republik Indonesia Tahun2003 Nomor 2003 Pasal 1 Ayat 15., n.d. - - - . UU No 20 Tahun 2003 Pasal 3 Fungsi Pendidikan, 2003.

RI, Peraturan Pemerintah. UU No. 20 Tahun 2003 Pasal 1. UU Pendidikan Nasional, 2003. Rusman. Belajar E Pembelajaran: Orientasi Standar Proses Pendidikan. Jakarta: 


\section{Sabda: Jurnal Teologi Kristen}

http://jurnalsttn.ac.id/index.php/SJT

p-ISSN 2772-3078, e-ISSN 2772-306X
Sekolah Tinggi Teologi Nusantara, Salatiga

Edisi: Volume 2, Nomor 2, November 2021

Prenadamedia Group, 2018.

Sahidillah, Muhammad Wildan, and Prarasto Miftahurrisqi. “Whatsapp Sebagai Media Literasi Digital Siswa." Jurnal VARIDIKA 1, no. 1 (2019): 52-57.

Sarwa. Pembelajaran Jarak Jauh : Konsep, Masalah Dan Solusi. Indramayu: Adab, 2021.

https:// books.google.co.id/books?id=OdQeEAAAQBAJ\&dq=Kurikulum+pembela jaran+jarak+jauh\&lr=\&hl=id\&source=gbs_navlinks_s.

Setijadi. Pendidikan Terbuka Dan Jarak Jauh. Universitas Terbuka. Jakarta: Pusat Penerbitan

Universitas tebuka, 2009. http://repository.ut.ac.id/5653/1/UTPTJJE2-ALL.pdf.

Siregar, Sofyan. Statistik Parametrik Untuk Penelitian Kuantitatif: Dengan Dilengkapi

Perhitungan Manual Dan Aplikasi SPSS Versi 17. Jakarta : Kencana. Jakarta:

RAJAWALI PRESS, 2013.

Sudarwan, Danim. Menjadi Peneliti Kualitatif. 1. Bandung: CV. Pustaka Setia, 2002.

Sudjana. Dasar-Dasar Proses Belajar Mengajar. Bandung: Sinar Baru Algensindo Offset, 2004.

Sugiyono. Metode Penelitian Manajemen. Bandung: CV. Alfabeta, 2014.

Tubagus, M, and S Kom. Model Pembelajaran Terbuka Jarak Jauh: Kajian Teoritis Dan Inovasi. Yoyakarta: Mesia Pustaka, 2021.

https:/ / books.google.com/books?hl=en\&lr=\&id=LXEyEAAAQBAJ\&oi=fnd\&pg=P A1\&dq=tpack + pembelajaran+daring\&ots=J2FPUYhOOC\&sig=ZsZn8G7EXidorNq Cx51AfNck56I.

Undang-Undang Dasar Tahun 1945 tetang Pendidikan. Pasal 31 Ayat (1) Dan (2), n.d.

Uno, H. Hamzah B. Model Pembelajaran: Menciptakan Proses Belajar Mengajar Yang Kreatif

Dan Efektif. Jakarta: Bumi Aksara. Jakarta: Bumi Aksara, 2010.

Valunaite Oleskeviciene, Giedre, and Jolita Sliogeriene. Research Methodology. Numanities - Arts and Humanities in Progress. Vol. 13. Semarang: KAO Press, 2020.

Warsita, Bambang, and Teknologi Pembelajaran. Landasan Dan Aplikasinya. Jakarta: Rineka Cipta. Vol. 135. Jakarta: Rineka Cipta, 2008. 